\title{
Effic iency Analysis with non parametric method: Illustration of the Tunisian ports
}

\author{
Arbia HLA ${ }^{1}$ \\ IUniversity of Ec onomics and Management science of Sfax, Tunisia.
}

\begin{abstract}
This paperapplies a non-parametric method to provide level technical efficiency for 7 Tunisian ports during 18 years (1998-2015). These ports represent different data set The use of the model of variable retums to scale (VRS) has led to interesting results. The results show that the most ports are characterized by low levels of technical efficiency, with the exception port of Rades. In addition, the result shows the variation of variable retums to scale and constant retums to scale of technical port's efficiency. Furthermore, we concluded that the panel data improves the efficiency estimates.
\end{abstract}

Key words: Technical efficiency, Tunisian ports, non parametric analysis

\section{INTRODUCTION}

The port efficiency is a signific ant indic a tor of economic development. Further, the most intemational trade is transported by sea. In addition, port efficiency, inc rea se transport costs as examined by [30] which founded that port efficiency is a relevant deteminant of maritime transport costs. Thus, in order to assist the ports to identify their own strengths, wea kness and opportunities in a competitive environment, it isnecessary to evalua te their efficiency.

Ports are complex organizations where operators engaged in diverse activities intersect, have different objectives and different subject of competition and regulation. Furthermore, it is appropriate to a nalyze the conc rete ac tivities of the seaport, whic $h$ must be spec ified accord ing to their characteristic s. The most a nalyzed activities are the developed ones for the port authorities and for the terminuses of manipulation of load, fundamentally, those of containers [8].

Two main reasons lead us to favor the DEA (compared to the parametric approach) to estimate the port efficiency. The first concems the difficulties of modeling the production process of port and the construction of a func tional form appropriate with the port activities. The second concems the multidimensional (multi-output) port.

In Tunisia $96 \%$ of foreign commercial trade is conducted by sea. At least $80 \%$ of manitime trade is processed through Rades port. The aim of this paper is to study port efficiency in Tunisia over the period 1998 to 2015 , by estimating of the technical efficiency frontier. This research tries to process the technic al efficiency by the application of the method (DEA). It used varia ble retumsto scale model DEA-BCC [5]. An output-oriented model has been adopted because the key objective of ports is to maximize the numbers of containers and the containerized freight quantity every year. This paper is structured as follows. The first section represents an introduction with a literature review on the technical port efficiency. The second section explains the methodology. The third section disc usses the empirical results. The last section treats the conclusion.

The first study treats the port efficiency sector was realized by Roll and Hayuth [29] which used DEA-CCR as mentioned by Chames et al [9] to assess the effic ienc y of 20 ports. Ac tua lly, there is prog ress in stud ies a na lyzing port efficiency and port productivity.

The table 1 show that the most popular search emerged data envelopment analysis DEA with BCC model and used Panel data as [22]; [20]; [21]; [23]; [3]; [12]; [13]; [7]; [31]; [26]; [25]; [18]; [14] and [32]. Other studies ha ve utilized cross-sec tional da ta to assess the effic ienc y of ports or temina ls such as [34]; [28]; [11]; [2]; [35], [1]; [16]; [36]; [19]; [24]; [27]; [4] and [17].

Table 1. literature review of tec hnical port effic iency with DEA method

\begin{tabular}{|l|l|l|}
\hline Author(s) (year) & Data type & Location \\
\hline Martinez-Budria et al,[22] & Panel & 26 Spanish ports (1993-1997) \\
\hline Wang et al, [34] & Cross-sectional & 57 intemational conta iner ports \\
\hline Rios and Maçada [28] & Cross-sectional & 23 MERCO SUR conta iner Teminals \\
\hline Cullina ne and Wang[11] & Cross-sectional & 69 European conta iner termina Is(2002) \\
\hline Ka isar et al, [20] & Panel & 20 US conta iner ports \\
\hline Al-Eraqi et al [2] & Cross-sectional & 22 ports in Middle East and East Africa \\
\hline Liu et al, [21] & Panel & 45 Chinese container temina Is \\
\hline Min and Park [23] & Panel & 11 Korean teminals \\
\hline
\end{tabular}


Logistics \& Sustainable Transport

Vol. 9, No. 1, February 2018, 51-58

doi: 10.2478/jlst-2018-0005

\begin{tabular}{|c|c|c|}
\hline Wu and Liang [35] & Cross-sectional & 77 world container ports \\
\hline Ab-Rosas and Ru Torres [1] & Cross-sectional & 29 Mexican coastal ports \\
\hline Al-Eraqi et al, [3] & Panel & 22 ports in East Africa and Middle East \\
\hline Cullina ne and Wang[12] & Panel & 25 leading container ports \\
\hline Hung et al, [16] & Cross-sectional & 31 c onta iner ports in Asia-Pacific region \\
\hline Wu and Goh [36] & Cross-sectional & 20 largest c ontainer ports in countries \\
\hline Kamble et al, [19] & Cross-sectional & 12 Indian ports \\
\hline Munisa my and Singh [24] & Cross-sectional & 69 ma jor Asian C onta iner ports \\
\hline Nia vis a nd Tsekeris [27] & Cross-sectional & 30 Europe \\
\hline Demirel et al,[13] & Panel data & 16 Mediterranean \\
\hline Bichou [7] & Panel data & 420 Intema tional c ontainer terminals \\
\hline Schøyen and Odeck [31] & Panel data & 24 conta iner ports in Norway, Nordic and UK \\
\hline Mokhtarand Shah [26] & Panel data & 6 Malaysien conta iner teminals \\
\hline Munisa my and J un [25] & Panel data & 30 Latin American \\
\hline Infante and Gutiérrez [18] & Panel data & 33 Asian Pacific region \\
\hline Ding et al, (2015) [14] & Panel data & 21 China ports \\
\hline Alma wsheki and Shah [4] & Cross sec tional & $\begin{array}{l}19 \text { Conta iner teminals in the Middle Eastem } \\
\text { region }\end{array}$ \\
\hline Hyun at al, [17] & Cross sectional & 21 Asia n container ports \\
\hline Tetteh et al, [32] & Panel data & Container port in china and 5 west Afric a \\
\hline
\end{tabular}

Source: own elaboration

The cross-sectional data and the panel data are the most commonly used in the literature. Cross-sectional data is data collected from multiple ports at a single point in time. This type of data enables researchers to evalua te and compare the effic ienc $y$ of different ports and to study the struc ture of the port ind ustry at a single point in time. In contrast, panel data, that is, data collected from multiple ports over multiple time periods can be used to observe and study changes in efficiency, management, and the impact of regulation of container ports. Finally, the regional loc ation is one of the most distinctive features of a port and therefore the selection of ports is important. Three types of sampling can be identified in the literature: intema tional, regional, a nd national ports.

The interest of this study isto a nalyze the effic ienc $y$ of the Tunisian ports, used panel data with several varia bles.

\section{METHODOLOGY}

According to [15] the technical effic iency is illustrated as the "fig.1" shows, the point P represents the inputs of the two factors, per unit of output, that the firm is observed to use. The isoquent SS' represents the various combinations of the two factors that the efficient firm used to produce unit output. The $Q$ represents an effic ient firm using the two factors in the same ratio as $P$. It can be seen that it produces the same output as $P$ using only a fraction OQ/OP as much of each factor. It could also be thought of as producing OP/OQ times as much output from the same inputs. It thus seems natural to define OQ/OP as the tec hnic al effic iency of the firm $P$. this ratio has the properties that a measure of efficiency obviously needs. It takes the value unity (or 100 percent) for a perfectly effic ient firm, and will become ind efinitely small if the amounts of input per unit output became indefinitely large. Moreover, so long as SS' has a negative slope, an increa se in the input per unit output of one factor will, imply lower. However, one also needs a mea sure of the extent to which a fim usesthe variousfactors of production in the best proportions, in view of their prices. Thus, in figure 1 if $A A^{\prime}$ has a slope equal to the ration of the prices of the two factors, $Q^{\prime}$ and not $Q$ is the optimal method of production, for although both points represent 100 percent. Tec hnic al effic iency produc tion at Q' will only be a fraction OR/OQ of those at Q. Further, if the observed firm were to change the proportions of its inputs until they were the same as those represented by $Q^{\prime}$, while keeping its technical efficiency constant, its costs would be reduced by a factors OR/OQ, so long as factor prices did not change. It is therefore reasonable to let this ratio measure the price efficiency of the observed firm $\mathrm{P}$, too. This argument is not entirely conclusion, as it is impossible to say what they will happen to technical efficiency of a firm as it changes the proportions of its inputs, but, with this qualific ation, it seems the best measure available. It also has the desirable property of giving the same price efficiency to firms using the factors in the same proportions. 


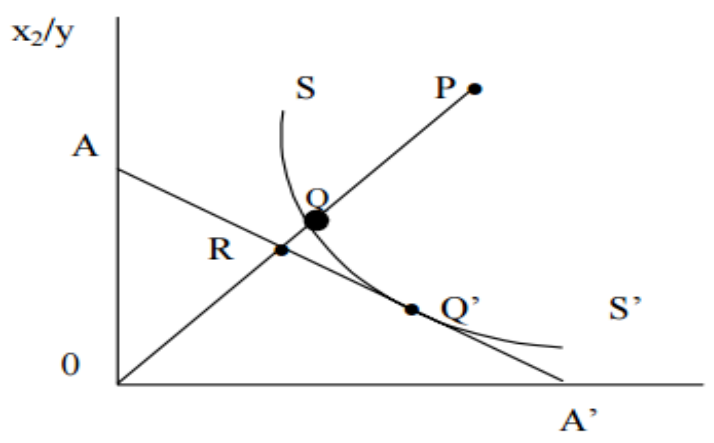

Figure 1: Technic al and alloc ative efficiency. Source: Farrell, 1957

If the observed firm were perfectly efficient, both technic ally and in respect of pric es, its costs would be a fraction OR/OP of what they in fact are. It is convenient to call this ratio the overall efficiency of the fim, and one may note it is equal to the product of the technical and price efficiencies.

DEA is a non-parametric mathematical programming model used to evaluate the relative efficiency of a group of entities or decision-making units (DMUs) in their use of multiple inputs to produce multiple outputs. The DEA models can be classified according to the type of efficiency measure to provide technical, allocative, economic, etc. It can be also c lassified to the orientation of the model input-oriented, output-oriented or inputoutput oriented. In addition, it can be classified by the type of retums to scale that characterizes the production technology constant or variable scale.

The DEA a pproach uses a linear programming model to construct a hypothetic al composite unit based on all units in the reference group. That is, the perfomance of each DMU is mea sured relative to the performance of all otherDMUs. The unit being evaluated can be judged relatively ineffic ient if the composite unit requires less input to obtain the output achieved by the unit being evaluated, or judged relatively.

The constant retum to scale (CRS) assumption is only appropriate when all the DMU's are operating at an optimal scale. Imperfect competition, constraints on finance, etc. may cause a DMU to be not operating at optimal scale. Banker, Chamesand Cooper [5] suggested an extension of the (CRS-DEA) model to account for variable retums to scale (VRS) situations. The use of the CRS specific ation when not all DMU's are operating at the optimal sc a le will result in mea sures of tec hnic a l effic iency, which a re confounded by scale effic iencies (SE). The use of VRS specific ation will permit the calc ulation of the TE devoid of these SE effects.

The technical efficiency was proposed by [5], it was decomposed overall technical efficiency, into pure technical effic iency and efficient technic al scale. To do this it need to compute the two models: CRS and VRS on the same data, if there is a difference in the two measurements for a particularDMU, and then it meansthat the DMU has scale inefficiency and inefficiency value is the difference between CRS and VRS measurement. The Global Technical Efficiency (GTE) can be decomposed into Pure Technical Efficiency (PTE) and Scale Efficiency (SE), Therefore $\mathrm{SE}=\Theta C C R / \Theta B C C$,Where, $C C R=$ constant retums to scale; $B B C=$ variables retums to scale.

The technical efficiency can be measured with output or input orientation, assuming to the goal of the researcher, in this paper the objective is to maximize the number of containers and the maximize the tonnage of fret conta inerized. The orientation is outp ut orientation as "fig. 2 " represents.

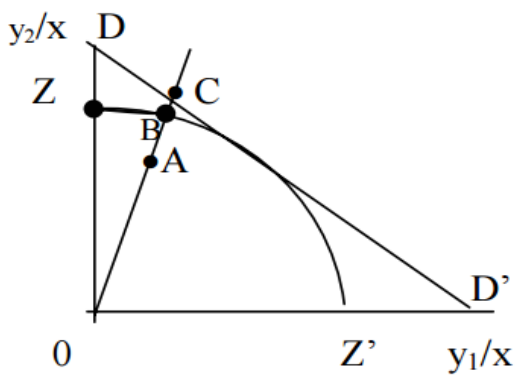

Figure 2: Output oriented effic iency measures. Source: Fa rrell 1957 
As it is described by "fig. 2, " the production frontier is represented by the isoquant $\mathbb{Z}$. The technical inefficiency of the firm defined by the point $A$ can be mea sured by the distance $A B$. It correspond sto the output proportions that can be increased without changing the input level. The measurement of the technical efficiency oriented output is defined by the ratio $\mathrm{ET}=\mathrm{OA} / \mathrm{OB}$.

To achieve the technical efficiency of Tunisian ports this paper adopts DEA-BCC model with output orientation. Each port is producing an output, $y$, using a set of $k=1, K$ inputs. The formal output-oriented DEA model can be declared as follows in (1):

$$
\begin{aligned}
& \operatorname{Max}_{\phi i} \lambda_{\mathrm{j}} \phi_{\mathrm{i}} \\
& \sum_{\mathrm{j}=1}^{\mathrm{n}} \lambda \mathrm{j} \mathrm{yj}-\phi \mathrm{iyi}-\mathrm{s}=0 \\
& \sum_{j=1}^{n} \lambda \mathrm{j} \mathrm{xkj}-\mathrm{xki}+\mathrm{ek}=0 \\
& \sum_{j=1}^{n} \lambda \mathrm{j}=1
\end{aligned}
$$

Where $\mathrm{j}=1, \mathrm{n}$ is the ports, the $\mathrm{s}$ and e are output and input slacks (both being $\geq 0$ ), and $\phi$ i measures the increa se in output potential for each port. Hence, $\phi_{i} \geq 1$.The weights, $\lambda$, on outputs and inputs give rise to variable retums to scale (VRS) in production and are due to [5]. In thiscase, the underlying technology of production can be one of increasing, dec reasing, or constant retums to scale. The more restrictive constant retums to scale (CRS) model originally developed by [9] eliminates the last equation. The technical efficiency with which each container port is based on its actual production accomplishment relative to its estimated production level for the frontier as in (2).

$$
\mathrm{TE}=\mathrm{y} / \sum_{j=1}^{n} \lambda \mathrm{j} \mathrm{yj}=\frac{\mathrm{y}}{\phi \mathrm{y}}=\frac{1}{\phi}
$$

Technical effic iency, therefore, varies between 0 and $1 ; 0 \leq \mathrm{TE} \leq 1$.

In this paper, the DEA methodology is a dapted to measure the efficiency ports. The choice of DEA is based on the small number of ports which constitute the sample. The solution of econometric models with a few of observations ma y tum out to be ineffic ient and unstable, because of the problem of limited degrees of freedom which typic ally arises. As it described in table 2, the DEA method has some advantages and disadvantages.

Table 2. advantages and disadvantages of the DEA method.

\begin{tabular}{|l|l|l|}
\hline & Advantages & Disavantages \\
\hline DEA method & -no a priori struc tural & -non parametric and deteministic a pproach. \\
& assumption is placed & -does not consider random noise a nd not allow \\
on the production & statistical hypothesis to be contrasted. \\
& process & -does not inc lude error term and not require \\
& & spec ifying a functional form. \\
& & -sensitive to the number of variable mea surements. \\
& & \\
\hline
\end{tabular}

Source: own elaboration

The inputsand output variablesshould reflect actual objectivesand the process of containerport production as accurately as possible [10]. In this paper, the main objective for the port is assumed to minimize the use of inputs to get the maximum outputs. Table 3 describes the variables collected for the 7 ports included in our study.

Four variables a re selected, the shipstraffic entry and exit port and Goodstraffics as input va riables then, the number of containers and the conta inerized freight qua ntity a s output variables. Indeed, it wanted to test, the technical efficiency of each port to disc over the resource of technical inefficiency.

Table 3. list of variables

\begin{tabular}{|l|l|l|}
\hline List of variables & & \\
\cline { 1 - 2 } Conta iners number (TEU) (number) & Y1 & \multirow{2}{*}{ Outputs va ria bles } \\
\cline { 1 - 2 } conta inerized freight qua ntity (tons) & $\mathrm{Y} 2$ & \\
\hline ships traffic entry and exit (number) & $\mathrm{X} 1$ & \multirow{2}{*}{ Inputs va ria bles } \\
\hline Goods traffic (tons) & $\mathrm{X} 2$ & \\
\hline
\end{tabular}


The data are obtained from the annual reports published by OMMP (merchant marine and ports office). It covers the period (1998-2015) and concem seven Tunisian ports, selected according to their size, type and availability of information.

"Fig.3" describes the average container number of each port in Tunisia over 1998-2015 period. It shows that the important number of containers is handled by the port of Rades more than (180.000) conta iners. The port of Sfax handled less than 10.000 containers and the other ports even less. This means that the port of Rades occupiesan important place in the national transport chain in container traffic.

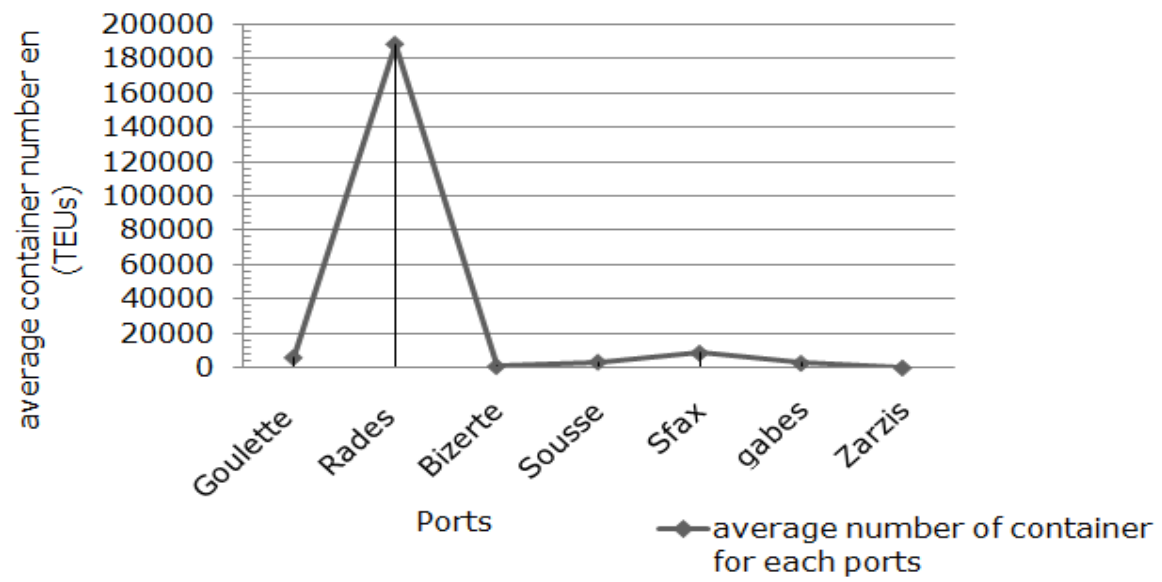

Figure 3: Average number of container en (TEUs) for each port.

\section{RESULTS}

This section presents and ana lyses the results of the overall technic al effic iency of 7 Tunisian ports. Panel data for 1998-2015 was estimated by applying DEA-BCC model with output-orientation, therefore, the analysis of results used to supply different recommendations for each efficient (inefficient) port.

The efficiency scores of the ports by each year of observation, and by a verage are reported in Table 4 . The scores are determined by deriving the VRS according to the DEA-BCC formulation. The use of the DEA-BCC gives the results of technical efficiency from constant retums to scale (crste) and technic al efficiency from variable retums to scale (vrste) as described in table 4.

Table 4. a verage score efficiency results

\begin{tabular}{|c|c|c|c|}
\hline & DEA-CCR & DEA-BCC & SE \\
\hline Goulette & 0.286 & 0.518 & 0.552 \\
\hline Rades & 1.000 & 1.000 & 1.000 \\
\hline Bizerte & 0.060 & 0.391 & 0.153 \\
\hline Sousse & 0.167 & 0.475 & 0.351 \\
\hline Sfax & 0.063 & 0.072 & 0.875 \\
\hline Gabes & 0.047 & 0.160 & 0.293 \\
\hline Zarzis & 0.022 & 0.944 & 0.023 \\
\hline Average & 0.235 & 0.508 & 0.462 \\
\hline
\end{tabular}

$(\mathrm{SE})=\mathrm{crste} / \mathrm{vrste}$

Table 4 shows that the average effic iency of Tunisian ports around to 0.235 with DEA-CCR model, 0.508 with the DEA-BCC and around to 0.462 for the SE. which means that the Tunisian port are not efficient en average. In addition, the analysis shows that only the port of Rades ac hieved score efficiency equal to 1 . For the others, we find 3 ports present an average effic iency sc ore between 0.5 and 0.8 and 3 ports between 0.05 and 0.4 .

The important finding indic ates that there is a score efficiency of 1 for the port of Rades and a score around to 0.875 for the port of Sfax. This result is explic ated by the reason that the port of Rades is specialized in the traffic of containerization. However, the port of Sfax is the most multipurpose port in Tunisia, it handled more container traffic and a mived after the port of Rades. 


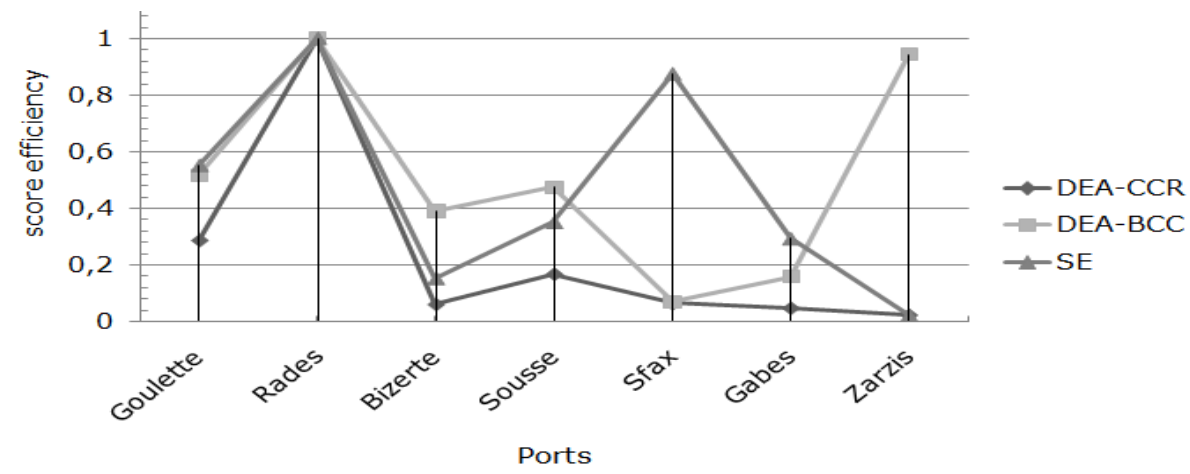

Figure 4:Average efficiency for each port. Source: own elaboration

The "fig.4" represents the variation of the average efficiency for each port. It shows that only the port of Rades is efficient with the DEA-CCR model, also only Rades, Sfax and Goulette are effic ient with the DEA-BCC. In addition, only Rades, Sfax and Goulette have score effic iency more than 0.5 .

The port of Bizerte has a SE more than 0.50 from 1998 to 2008 and leave to be completely inefficient between 2009 to 2015 which make SE less than 0.05. The same conclusion it founded in the port of Gabes which achieved inefficiency scale in the last years. This result has two reasons, first that the inputs and outputs dec rease in the last years.

There is little va riation in efficiency scoresobtained by the ind ividual portsa cross the years of observation. This indicates that the relative position of the ports to the frontier is stable through the period studied. There are explanations for the variation in effic iency scores displayed by certa in ports.

The va riations of sc ores effic ient a re between 1 and 0.062 an avera ge for Tunisia $n$ ports. These results a re similar to the results of [31] that founded the va riations of Norwegian ports efficiency sc ores which, a re 1 forthe effic ient ports while, others score as low as 0.27 . These results are also comparable with [33], where the technical efficiency of 22 European ports was estimated, and it was concluded that an average port could handle 0.40 more traffic with the some resources. However, as every port has its specific characteristic s, including the hinterland transportation system, an optimal production ac hievable in one port is not nec essarily achievable for other ports [34].

Moreover, according to this methodology we find that technic al efficiency varies between ports in time. This variability is not the same for all ports. In other words, technical efficiency does not vary independently. In addition, we observe that it does not improve over the last years.

The retums to scales of Tunisian ports are increasing between 1998 and 2015. This is consistent with the descriptive statistics, which shows that approximately all Tunisian ports have a gradual evolution in tems of va riables studied.

The scale inefficiency observed is due to ports that operate with increasing retums. This indicates that ports can increase their scale of operations to be more efficient. In the last years all Tunisian ports operate with increasing retums to scale. Indeed, Tunisian ports need to increase their operating scale in order to become scale efficient because it a ppears that they a re specialized expect the port of Sfax which, is multip urpose port.

\section{CONCLUSION}

The evaluation and measurement of efficiency take into account the specific nature of the study area and used several approaches: parametric and nonparametric. In this context, we used the implementation of the non-parametric DEA method to evaluate the tec hnic al effic iency of Tunisian ports. This study providesa previous idea about technic al effic iency of Tunisian ports.

In view of other researchers measuring port efficiency is complicated for two main reasons: the first is the designation of the method because, the modeling of the port production functions is delicate. The second is the selection of inputs and output variables, because the port is a multidimensional sector.

Numerous conclusions can be drawn from this study, as follows. Among the 7 ports in Tunisia only the port of Rades is efficient, the port of Sfax achieved a value of 0.892 is considered efficient in comparison with the rest of the port that are ineffic ient. Zarzis port shows the lowest level of a verage efficiency with a score of 0.0062 . All the inefficient ports show increasing retums to scale. Ports need to increase their operating scale in order to be efficient.

The result obtained shows that the efficiency scores are, on a verage lower, while the retums to scale growing in time. In addition, the empirical case, we conclude that the port of Sfax and Rades are the most technic ally efficient. 
The model (DEA-BCC) produc es only a partial evaluation of tec hnic al efficiency. Thus, their result cannot be interpreted as a specific measure of technic al efficiency. Therefore, this study has several limitations that are caused by the port sector specificities and the available data, or the limits granted to the DEA models. On the other hand, the advantage of this research appears at the using of panel data approach which is more appropriate for capturing the dynamics of capacity optimization, efficiency changes over the years and the tec hnical innova tions that may eventually occur.

\section{ACKNOWLEDGMENT}

The a uthor is grateful for the construc tive comments provided by reviewers.

\section{REFERENCES}

1. Ablanedo-Rosas, J.H. and Ruiz-Torres, A.J. (2009), Benchmarking of Mexican ports with data envelopment analysis. Intema tional J oumal of Shipping and Transport Logistics 1(3): 276-294.

2. Al-Eraqi, A., Mustafa, A., Khader, A. and Barros, C. (2008), Effic iency of Middle Eastem and East African sea ports: Ap plic ation of DEA using window a nalysis. European J oumal of Scientific Research 23(4): $597-$ 612.

3. Al-Eraqi, A.S., Mustafa, A. and Khader, A.T. (2010), An extended DEA wind ows analysis: Middle East a nd East Afric an seaports. J oumal of Ec onomic Studies 37(2): 208-218.

4. Alma wsheki, E. S., Shah, M. Z (2015), Technic al Effic iency Analysis of Conta iner Temina ls in the Middle Eastem Region, The Asian J oumal of Shipping and Logistic s 31(4): 477-486.

5. Banker, R.D.,Chames, A. and Cooper, W.W.(1984), some models for estimating technical and scale ineffic iencies in data envelopment analysis. Management Science 30(9):1078-1092.

6. Barros, C. P., Felic io, J.A., Leite, R. (2012), Productivity analysis of Brazilian seaports. Maritime Polic y \& Management 39(5): 503-523

7. Bichou, K. (2012), An empirical study of the impacts of operating and ma rket conditions on conta inerport efficiency and benchmarking. Research in Transportation Economics 42(1):28-37.

8. César L N-C and Zamora-Torres, A. I. (2014), Economic Efficiency of the Intemational Port System: An Analysis through Data Envelopment, Intemational Business Resea rch 7(11):108-116.

9. Chames, A., Cooper, W.W. and Rhodes, E. (1978), Measuring the efficiency of decision making units. European J oumal of Operational Research 2(6): 429-444.

10. Cullinane, K., Song, D.-W., Ji, P. and Wang, T.-F. (2004), An application of DEA windows a nalysis to conta iner port production effic iency. Review of Network Economic s3(2): 7.

11. Cullinane, K.P. and Wang, T.-F.(2006), The effic iency of European c ontainerports: A cross-sectional data envelopment a nalysis. Intemational J oumal of Logistic s Resea rch and Applic ations 9(1):19-31.

12. Cullina ne, K. and Wang, T.-F. (2010), The effic ienc y a na lysis of conta inerport production using DEA panel data approaches. OR Spectrum 32(3): 717-738.

13. Demirel, B., Cullinane, K. and Haralambides, H. (2012), Conta iner teminal efficiency and private sector participation: an application to Turkey and the Eastem Mediterranean. In: The Blackwell Companion to Maritime Ec onomic s: 571-598.

14. Ding, ZY., J o, G.S., Wang, Y. and Yeo, G.T. (2015), The Rela tive Effic iency of Conta iner Terminals in Small and Medium-Sized Ports in China, The Asian J oumal of Ship ping and Logistic s 31: 231-251.

15. Farrell, M.J . (1957), The mea surement of effic iency. J oumal of the Royal Society A (120): $257-271$.

16. Hung, S.W., Lu, W.M. and Wang, T.P. (2010), Benchmarking the operating efficiency of Asia container ports. European J oumal of Operational Research 203(3): 706-713.

17. Hyun, M. J., Ho, P., Sang, Y. Kim. (2016), Effic iency Ana lysis of Major Container Ports in Asia: Using DEA and Shannon's Entropy, Intemational J oumal of Supply Chain Management 5 (2):1-6

18. Infante, $Z$ and Gutiérrez, A. (2013), Port Effic iency in apec 1. Méxic o y la Cuenca del Pac ífic o.

19. Kamble, Sachin S., Raoot, Arun D. and Khanapuri, Vivek B. (2010), Improving port efficiency: a comparative study of selected ports in India, Intemational J oumal of Shipping and Transport Logistic S 2(4), pp. 444-470.

20. Kaisar, E.I., Pathomsin, S. and Haghani, A. (2006), Effeciency measurement of US ports using data envelopment a nalysis. In: National Urban Freight Conference, Long Bea ch, CA,1-3 February, p. 16.

21. Liu, B.-L, Liu, W.-L. and Cheng, C.-P. (2008), the effic iency of container terminals in mainland China: An application of DEA a pproach. $4^{\text {th }}$ Intemational Conference on Wireless Communications, Networking and Mobile Computing, Wi COM '08. 2008 IEEE Xplore digital library: 1-10.

22. Martinez-Budria, E., Armas, R.D., Ibanez, M.N. and Mesa, R.(1999), A study of the effic iency of Spanish port authorities using Data Envelopment Analysis. Intemational J oumal of Transport Ec onomic s 26(2): 237-253. 
Logistics \& Sustainable Transport

Vol. 9, No. 1, February 2018, 51-58

doi: $10.2478 /$ jlst-2018-0005

23. Min, H. and Park, B.I. (2005), Evaluating the inter-temporal efficiency trends of intemational container teminals using data envelopment analysis. Intemational J oumal of Integrated Supply Management 1(3): 258-277.

24. Munisamy, S. and Singh, G. (2011), Benchmarking the effic iency of Asian conta iner ports, African jouma I of business ma nagement (5): 1397-1407.

25. Munisamy, S. and J un, O.(2013), Effic iency of Latin Americ a n conta iner seaports using DEA, Proceed ings of $3^{\text {rd }}$ Asia-Pacific Business Research Conference, 25-26 February 2013, Kuala Lumpur, Malaysia, ISBN: 978-1-922069-19-1.

26. Mokhtar, k. and Shah, M.Z (2013), Efficiency of Operations in Container Terminals: A FrontierMethod. European J oumal of Business and Management 5(2): 91-106.

27. Nia vis, S. and Tsekeris, T. (2012), Ranking and c a uses of ineffic iency of c onta iner sea ports in So uth-Ea stem Europe, European Transport Research Review 4(4): 235-244.

28. Rios, L. and Maçada, A. (2006), Analysing the relative effic ienc y of c onta iner termina ls of Merc osur using DEA. Maritime Ec onomics \& Logistic s 8(4): 331-346.

29. Roll,Y. and Hayuth, Y. (1993), Port performa nce comparison a pplying data envelopment a na lysis (DEA). Maritime Policy \& Management 20(2): 153-161.

30. Sanchez, R.J., Hoffman, J., Micco, A., PI Zzolitto, G.V., Sgut, M., and Wilmsmeier, G. (2003), “Port efficiency and intemational trade: Port efficiency as a determinant of maritime transport costs," Maritime Economic s \& Logistic s, Vol.5, pp.199-218.

31. Schøyen, H., Odeck, J . (2013), The technic al effic iency of Norwegian container ports: A compa rison to some Nordic and UK container ports using Data Envelopment Analysis (DEA). Maritime Economics \& Logistic s 15(2):197-221.

32. Tetteh, E. A., Yang, H., Gomina, M. F. (2016), Container Ports Throughput Analysis: A Comparative Evaluation of China and Five West African Countries, Intemational J oumal of Engineering, Research in Africa (22): 162-173.

33. Trujillo, L and Tovar, B. (2007), The European port industry: An analysis of its economic efficiency. Maritime Economic s \& Logistic s9(2): 148-171.

34. Wang, T-F., Song, D-W., Cullina ne, K. (2003), Conta iner Port Production Effic iency: A Compa rative Study of DEA and FDH Approac hes, J oumal of the Eastem Asia Soc iety for Transportation Studies (5): 698-713.

35. Wu, J. and Liang, L(2009), Performances and benchmarks of container ports using data envelopment a nalysis. Intemational J oumal of Shipping a nd Tra nsport Logistic s 1(3): 295-310.

36. Wu, Y-C. J. and Goh, M. (2010), Container port efficiency in emerging and more advanced markets, Transportation Research Part E: Logistics and Transportation Review (46): 1030-1042.

\section{AUTHORS}

A. Arbia. Hali is a doctors of ec onomics science, university of Ec onomic sand Management science of Sfax; La boratory URED, Airport road, km 4, POB: 1088, Postal code 3018 Sfax, Tunisia (e-ma il: arbiaarbiahlali@yahoo.fr)

Manuscript received by 3 July 2017. 